Psychiatry and Its Discontents 



\section{Psychiatry and Its Discontents}

Andrew Scull

甲

U N IVERSITY OF CALIFORNIA PRESS 
University of California Press, one of the most distinguished university presses in the United States, enriches lives around the world by advancing scholarship in the humanities, social sciences, and natural sciences. Its activities are supported by the UC Press Foundation and by philanthropic contributions from individuals and institutions. For more information, visit www.ucpress.edu.

University of California Press

Oakland, California

(C) 2019 by Andrew Scull

Library of Congress Cataloging-in-Publication Data

Names: Scull, Andrew, 1947- author.

Title: Psychiatry and its discontents / Andrew Scull.

Description: Oakland, California : University of California Press, [2019] | Includes bibliographical references and index. |

Identifiers: LCCN 2018055944 (print) | LCCN 2018058799 (ebook) | ISBN 9780520973572 (Ebook) | ISBN 9780520305496

(cloth : alk. paper)

Subjects: LCSH: Psychiatry.

Classification: LCC RC454 (ebook) | LCC RC454 .s3567 2019 (print) | DDC $616.89-\mathrm{dc} 23$

LC record available at https://lccn.loc.gov/2018055944

Manufactured in the United States of America

$\begin{array}{lllllllll}27 & 26 & 25 & 24 & 23 & 22 & 21 & 20 & 19\end{array}$

$\begin{array}{llllllllll}10 & 9 & 8 & 7 & 6 & 5 & 4 & 3 & 2 & 1\end{array}$ 
For those who have suffered and even now suffer from serious mental troubles:

I should like to call you all by name,

But they have lost the lists.

Anna Akhmatova, Requiem and Poem without a Hero, translated by D.M. Thomas

And for my friends Amy Forrest and Stephen Cox with gratitude for kindness I cannot adequately repay 
